$$
\begin{aligned}
& \text { اثر اقليم بر ميزان آب، خفتتكى و الثوى بيان دهيدرينها در دانةُ يسته } \\
& \text { الهه زمانى بهرام آبادى'، يريسا جنوبى'، فرخنده رضانزاد' }
\end{aligned}
$$

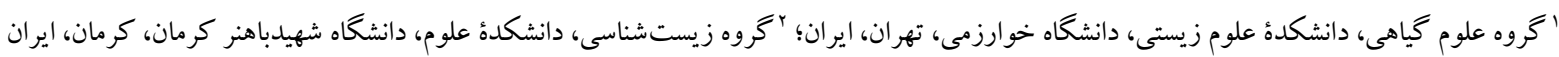

$$
\begin{aligned}
& \text { مسئول مكاتبات: الهه زمانى بهرام بادى، لelaheh_zamani@yahoo.com }
\end{aligned}
$$

\title{
The effect of climate on water content, dormancy and dehydrins expression pattern in pistachio seeds
}

\section{Elaheh Zamani Bahramabadi ${ }^{1}$, Parisa Jonoubi ${ }^{1}$ \& Farkhondeh Rezanejad $^{2}$}

\author{
${ }^{1}$ Department of Plant Sciences, Faculty of Biological Sciences, Kharazmi University, Tehran, Iran; ${ }^{2}$ Department of \\ Biology, Faculty of Sciences, Shahid Bahonar University of Kerman, Kerman, Iran \\ Corresponding author: Elaheh Zamani Bahramabadi, elaheh_zamani@yahoo.com
}

\begin{abstract}
The environmental conditions which the parent plant has undergone during seed development can affect many properties of the seeds such as degree of dormancy, weight and the amount of their compounds. In this study, mature pistachio seeds of Ahmadaghaei cultivar, collected from the two cities of Rafsanjan and Shahrbabak located in Kerman Province (Iran), were compared. It was found that the seeds collected from Shahrbabak being a cooler and wetter region had a longer dormancy, although the water content of the two seed series were similar. Dehydrin proteins generally play a role in protecting plant cells against dehydration stress. Dehydrin contents of the cotyledons and embryonic axes of the two seed series were compared by western blot method using an antibody against the conserved $\mathrm{K}$ segment in dehydrin proteins. It was found that the cotyledons had five dehydrin versions with molecular weights of $23,25,32,39$ and $48 \mathrm{kDa}$, the expression of which not being influenced by environmental factors. It was found that the embryonic axes had seven other versions of dehydrin with weights of 17, 19, 20, 28, 67, 77 and $98 \mathrm{kDa}$ in addition to those five versions. This shows higher protection of embryonic axes compared with the cotyledons. The 25 and $28 \mathrm{kDa}$ versions had higher expression levels in embryonic axes of Shahrbabak seeds, while the $39 \mathrm{kDa}$ version had a higher expression level in embryonic axes of Rafsanjan seeds.
\end{abstract}

Keywords. cotyledon, development, embryonic axis, environment, western blotting 
(Saber Amoli et al., 2004)

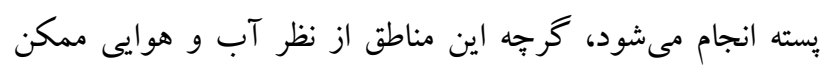
است بسيار متفاوت باشند.

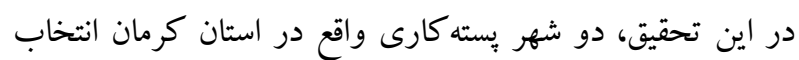



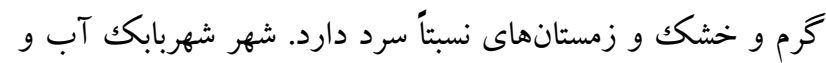

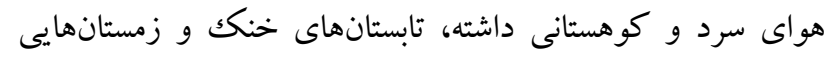

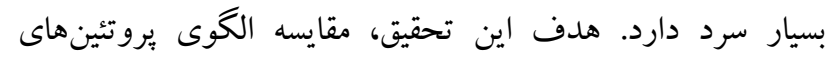


در زمان تكوين، روى الكوى اين بروتئينها در دانه تعيين شود.

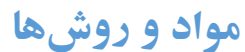

مواد Fياهى از هر كدام از شهرهاى رفسنجان و شهربابكى، يكك باغ زير

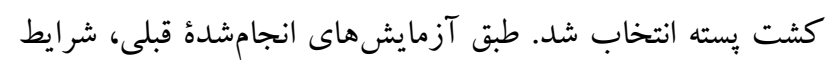

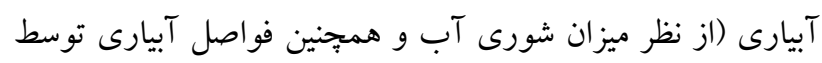

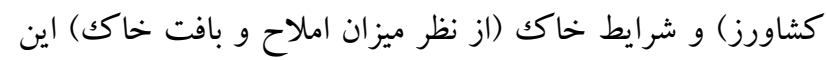

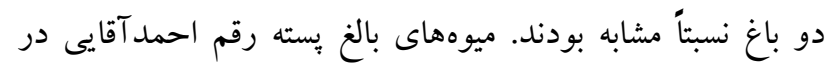

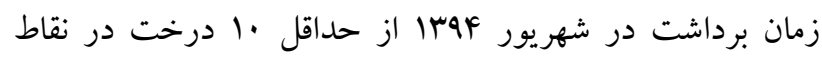




جدول آ آورده شده است (weather.kr.ir).

\section{محتواى آب دانهها} بعد از انتقال ميوههاى تازه به آزمايشگاه، فرابر ميوه از دانههاى

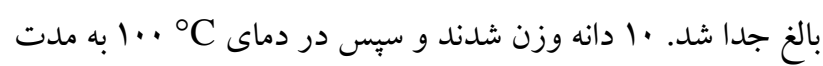

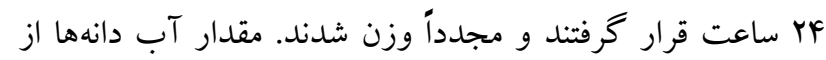
طريق اختلاف وزن تر و خشكك بهدست آمد و بهصورت درصدى از وزن اوليه بيان شد. اين آزمايش با سه تكرار انجام شد

.(Kalemba \& Pukacka, 2012)

\section{دورؤ خفتكى دانهها}

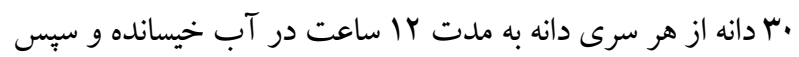
بين كاغذ مرطوب قرار گرفته و در اتاق نكهدارى شدند تا رويش يابند. بهطور هفتهاى، دانهاى رويش يافته شمرده و از بقيه دانهها جدا شدند. اين كار به مدت هشت ماه ادامه يافت. يكك دانه وقتى رويش يافته در


با سه تكرار انجام شد (Kalemba \& Pukacka, 2012).
مقال

شرايط محيطى كه گياه والد طى تكوين دانه گذرانده است، مى تواند روى بسيارى از خصوصيات دانهها تأثير كذارد. دانه كياهان يكى گونه كه شرايط محيطى متفاوتى را طى تكوين خود

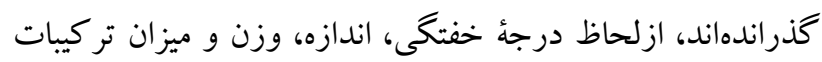
آلى و معدنى تفاوت هاى جشمخيرى دارند. اين آثار احتمالاً ناشى از تغييرات در مقدار، تحركك يا فعاليت تنظيم كنندهاى رشد است (Fenner, 1991, 1992; Jaganathan, 2016) LEA دانه شروع به ازدستدادن آب براى ورود به خفتخى مى كند

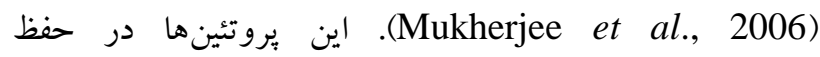
خوديايدارى درونسلولى و حفاظت از درشتمولكولها و غشاها، عليه تنشهاى اسمتيك و اكسايشى شركت دارند ( Bremer et

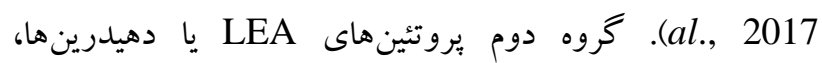
يروتئينهايى هستند كه بهطور عمومى در باسخ به محرككهاى محيطى مانند سرما، خشكى و شورى كه موجب آبخيرى سلولها مى شوند، القا مى شوند و در ايجاد تحمل به آبخيرى نقش كليدى بر ماري عهده دارند (Banerjee \& Roychoudhury, 2016). از آنجا كه دهيدرينها قادرند تا ساختار خود را به سرعت در پِاسخ به شرايط درونسلولى تغيير دهند، مىتواند اعمال متنوعى را در سلول گياهى به عهده بخيرند. مشخص شده كه زنهاى دهيدرين موجود در زنوم هر كونه، اغلب بيان ويزه اندام، ويزه بافت بهن Vaseva et al., ) يا ويثه مرحله تكوينى (Kermode, 1997) 2014) دارند. همجنين هر زن دهيدرين ممكن است ياسخگً به Wang et al., ) يك، جند يا همه تنشهاى غيرزيستى باشد 2014). دهيدرينها دامنه وسيعى از وزن مولكولى بين 9 تا ... كيلودالتون دارند و قطعه بسيار حفاظتشده ها اسيد آمينهاى غنى از ليزين (EKKGIMDKIKEKLPG) كه قطعه K ناميده مىشود نشان ويز گیى آنهاست (Takahashi et al., 1994).


Anacardiaceae ايران و بسيارى از مناطق ديكر جهان كشت داده مىشود ( Zamani Bahramabadi et al., 2018 . سهم درخورتوجهى از توليد و سطح زير كشت يسته ايران به استان كرمان اختصاص دارد. اين استان

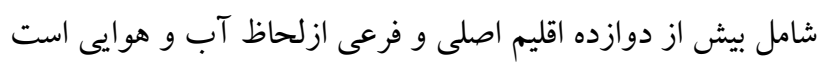


منثايج

ميز ان آب دانهها

نتايج آزمون t مستقل نشان دادند كه ميزان آب دان دانها ها بين دو منطقه

$$
\text { تفاوت معنى دار نداشت (جدول Y). }
$$

\section{دوره خفتكى دانهها}

نتايج آزمون t مستقل نشان دادند كه دوره خفنتخى دانها منطقه تفاوت معنىدار داشت و براى دانهاى جمع آورى شده از

$$
\begin{aligned}
& \text { شهربابك طولانى تر بود (جدول Y). } \\
& \text { الكوى دهيدرينها در لٍه }
\end{aligned}
$$

بررسىهاى لكه گذارى وسترن حضور ه باند دهيدرين با وزن إنه


(شكل (1). تراكمسنجى باندها تفاوت معنىدارى بين دانهاى

جمع آورى شده از دو منطقه نشان نداد (جدول ؟انم).

\section{الكوى دهيدرينها در محور رويانى}

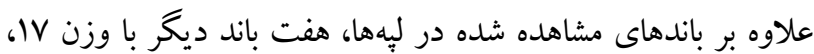

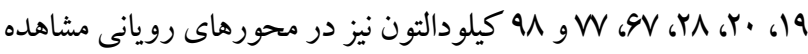

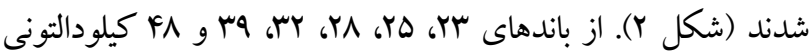

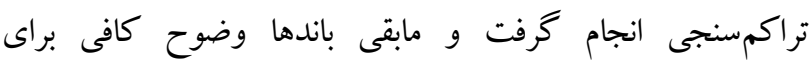

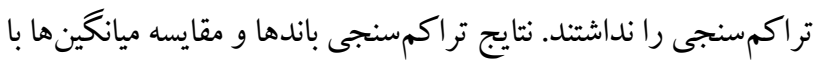

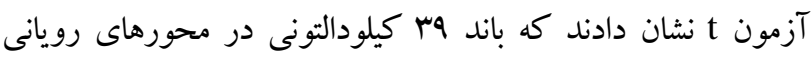
دانهاى جمع آورىشده از رفسنجان نسبت به دانههاى جمع آورى شده داند

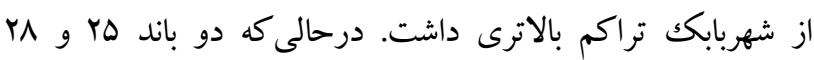

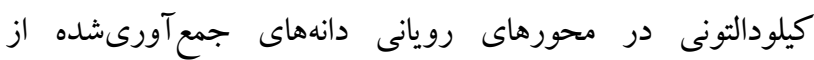

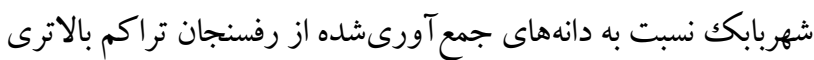

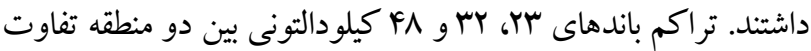

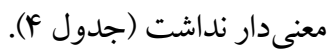

\section{بحث}

دانههاى جمع آورىشده از رفسنجان از درختانى بهدست آمدند كه دماى بالاتر و رطوبت و بارش پيايينترى را در طول فصل زراعى تحمل كرده بودند. درحالى كه درختان والد دانهاى بـائ

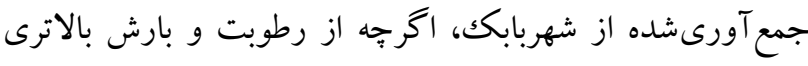
برخوردار بودند، اما شرايط دمايى پايين ترى داشتند (جدول (). از از

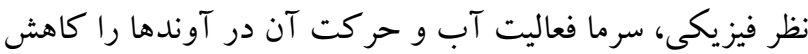
مىدهد (Close, 1997)، و ازآنجاكه دانه در تمامى مراحل تكوين خود توسط بافتهاى نسبتاً ضخيم و آبدار تخمدان و و واند
استخر اج يروتئين و لكه كذارى وسترن (Western blot) براى استخراج بروتئين، بوسته دانه از دانه سبز جدا شد. سبس

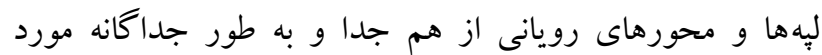

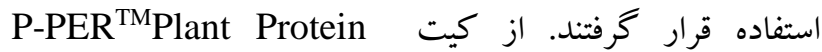
(Thermo Scientific, US) Extraction kit بروتئين كل استفاده شد و سبس بروتئينهاى مقاوم به گرما كه شامل دهيدرينها هم مىشوند، طبق روش لروناك (thermostable) Panza و همكاران (2007) از بقيه يروتئين ها جدا شدند. براى

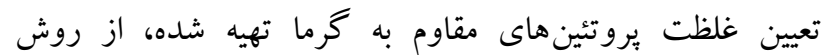
برادفورد و آلبومين سرم گاو به عنوان استاندارد استفاده شد (Bradford, 1976)

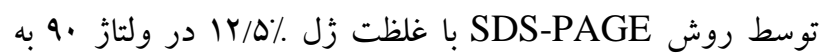
مدت r ساعت الكتروفورز شدند (Laemmli, 1970). از نشانغر وزن مولكولى بروتئين ها نيز استفاده شد. سبس بروت بروتئين ها در ولتاز

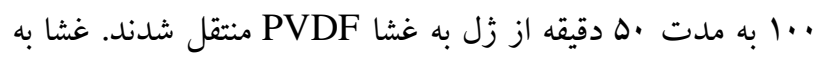

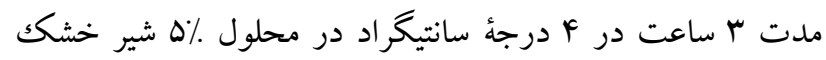



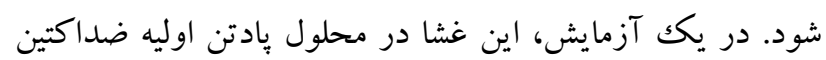
با غلظت .. (Agrisera, AS132640, Sweden) كنترل قرار گرفت. در آزمايشى ديخر، غشا در محلول پِادتن اوليه

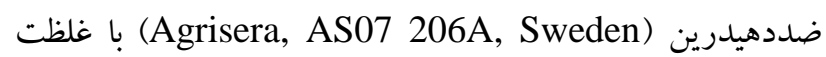



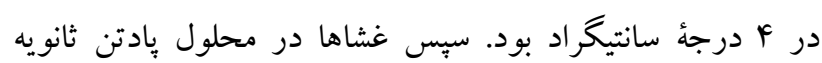

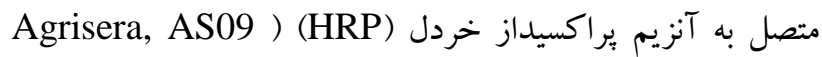
602, Sweden در غلظت ....1/ براى ا ساعت در دماى اتاق قرار داده شدند. پِ از شستوشو با بافر تريس سالين تويين

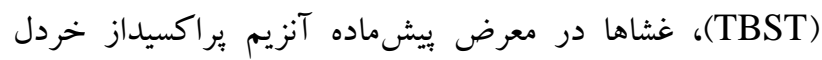

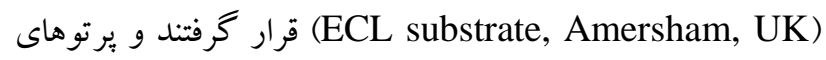
لومينسانس روى فيلم راديولوزى ظاهر شدند. از فيلمها عكسبردارى انجام شد و تراكم باندها با استفاده از نرمافزار

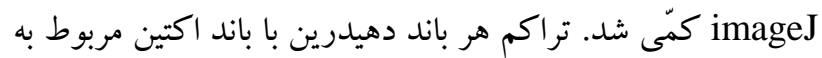
خود تنظيم شد. اين آزمايش با جهار تكرار انجام كرفت تجزيه و تحليل آمارى دادهها به شكل ميانكين تكرارها د انحراف آماري استاندارد نشان داده


در سطح معنى دارى هـ/ • انجام گرفت. 


$$
\text { جدول ا- اطلاعات هواشناختى دو منطقه جمع آورى دانه بِته. }
$$

Table 1. Meteorological data of two pistachio seed collection areas.

\begin{tabular}{|c|c|c|}
\hline سال زراعى qF-9F & رفسنجان & شهربابك \\
\hline ميانكين دما (م) & $19 / 14$ & $10 / 49$ \\
\hline ميزان بارش (mm) & $11 \cdot / \mathrm{V}$ & $190 / r$ \\
\hline ميانخين رطوبت نسبى (٪) & $r N / Y$ & $\mathrm{rg/N}$ \\
\hline
\end{tabular}

$$
\text { جدول r- -نتايج آزمون t مستقل جهت مقايسه ميانگين ميزان آب و دوره خفتخى دو گروه دانه بِته جمع آورى شده از دو منطقه مختلف. }
$$

Table 2. The results of independent t-test used to compare the mean of water content and dormancy period of two

\begin{tabular}{|c|c|c|c|c|c|c|}
\hline درجهُ آزادى & معنى دارى & مقدار t & انحراف استاندارد & ميانكين & ( & متغير \\
\hline \multirow[t]{2}{*}{$r$} & \multirow[t]{2}{*}{.$/ \% \pi$} & \multirow[t]{2}{*}{$r / \backslash A F$} & $\cdot / \Delta V \Delta$ & $r 1 / 9$. & رفسنجان & \multirow[t]{2}{*}{ ميزان آب (.) } \\
\hline & & & $\cdot / \Delta Q Y$ & $r q / r$. & شهربابك & \\
\hline \multirow[t]{2}{*}{ F } & \multirow[t]{2}{*}{.$/ 10$} & \multirow[t]{2}{*}{$-F / . \Delta F$} & $1 / N r$ & 191 & رفسنجان & \multirow[t]{2}{*}{ خفتكى (روز) } \\
\hline & & & $f / 91$ & rMA & شهربابكك & \\
\hline
\end{tabular}
groups of pistachio seeds collected from two different regions.

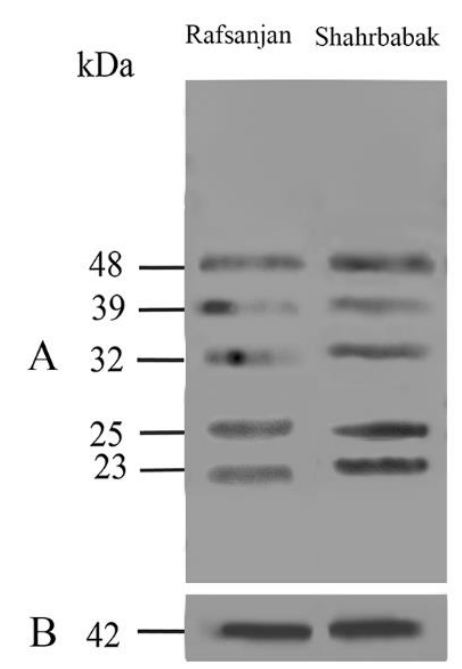





Fig. 1. Pattern of dehydrin proteins in pistachio cotyledons collected from two areas. A. Bands with molecular weights of 23, 25, 32, 39 and $48 \mathrm{kDa}$. B. The actin band with a molecular weight of $42 \mathrm{kDa}$.

$$
\text { جدول r- - نتايج آزمون t مستقل جهت مقايسه ميانگين تراكم باندهاى دهيدرين در لِه دو گروه دانهُ پِته جمع آورىشده از دو منطقه مختلف }
$$

\begin{tabular}{|c|c|c|c|c|c|c|}
\hline درجهُ آزادى & معنى دارى & مقدار t & انحراف استاندارد & ميانگين & كروه & متغير \\
\hline \multirow[t]{2}{*}{$f$} & \multirow[t]{2}{*}{$\cdot / 1$} & \multirow{2}{*}{$-Y / I I$} & $1 / Y \mu$ & $1 \mathrm{~V} / \mathrm{Vq}$ & رفسنجان & \multirow[t]{2}{*}{ F^kDa } \\
\hline & & & $1 / \mathrm{WV}$ & Yr/TrV & شهربابك & \\
\hline \multirow[t]{2}{*}{ f } & \multirow[t]{2}{*}{$\cdot / 10$} & \multirow[t]{2}{*}{ I/VY } & Y/AY & $r V / I V$ & رفسنجان & \multirow[t]{2}{*}{ rakDa } \\
\hline & & & $r / q r$ & IN/AY & شهربابك & \\
\hline \multirow[t]{2}{*}{$F$} & \multirow[t]{2}{*}{$\cdot \pi \Delta$} & \multirow[t]{2}{*}{$1 / \cdot r$} & $F / r$. & $r \cdot / \Lambda Y$ & رفسنجان & \multirow[t]{2}{*}{ rrkDa } \\
\hline & & & $F / A r$ & $r F / I I$ & شهربابك & \\
\hline \multirow[t]{2}{*}{$F$} & \multirow[t]{2}{*}{$\cdot / F F$} & \multirow[t]{2}{*}{$-\cdot / A F V$} & $V / \cdot F$ & $Y Y / Y \Delta$ & رفسنجان & \multirow[t]{2}{*}{$\mathrm{r} \Delta \mathrm{kDa}$} \\
\hline & & & $r / r q$ & rN/Ar & شهربابك & \\
\hline \multirow[t]{2}{*}{$F$} & \multirow[t]{2}{*}{$\cdot / T F A$} & \multirow[t]{2}{*}{$-1 / r \Delta r$} & $F / V^{F}$ & $r 1 / 19$ & رفسنجان & \multirow[t]{2}{*}{ rrkDa } \\
\hline & & & $\Delta / v \Delta$ & $r \mid / Y F$ & شهربابك & \\
\hline
\end{tabular}

Table 3. The results of independent t-test used to compare the mean of dehydrin bands density in cotyledons of two groups of pistachio seeds collected from two different regions. 


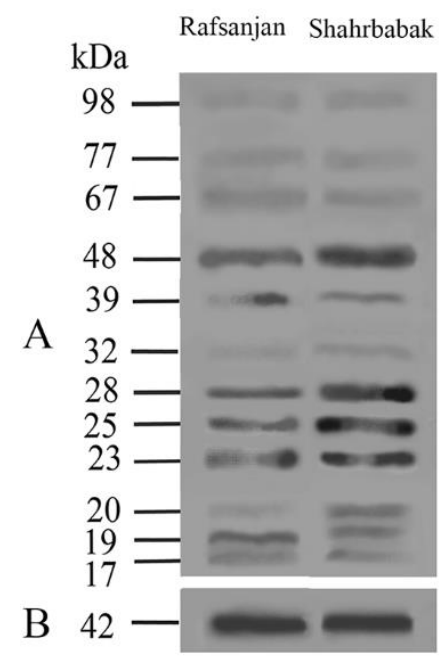

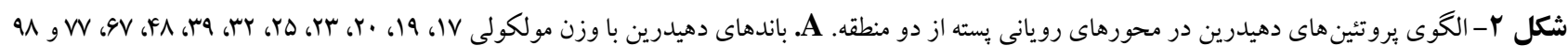

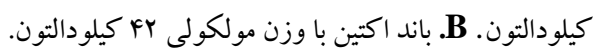

Fig. 2. Pattern of dehydrin proteins in pistachio embryonic axes of seeds collected from two areas. A. Bands with molecular weights of $17,19,20,23,25,32,39,48,67,77$ and $98 \mathrm{kDa}$. B. The actin band with a molecular weight of 42 $\mathrm{kDa}$.

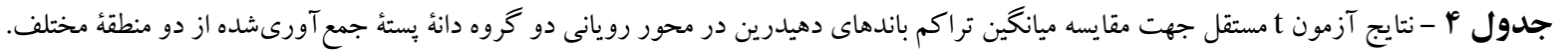

Table 4. The results of independent t-test used to compare the mean of dehydrin bands density in embryonic axes of two groups of pistachio seeds collected from two different regions.

\begin{tabular}{|c|c|c|c|c|c|c|}
\hline درجة آزادى & معنىدارى & مقدار t & انحراف استاندارد & ميانكين & كروه & متغير \\
\hline \multirow[t]{2}{*}{ F } & \multirow[t]{2}{*}{$\cdot / N \backslash \Lambda$} & \multirow[t]{2}{*}{$-\cdot / r A V$} & $r / r \Delta$ & $r \Delta / N \Delta$ & رفسنجان & \multirow[t]{2}{*}{$r \wedge \mathrm{kDa}$} \\
\hline & & & $r / F$. & $\mathrm{TV} / \Delta \mathrm{V}$ & شهربابكك & \\
\hline \multirow[t]{2}{*}{ f } & \multirow[t]{2}{*}{.$/ 1$} & \multirow[t]{2}{*}{$F / 4 F$} & $1 / \mathrm{VV}$ & $\mid r / r$. & رفسنجان & \multirow[t]{2}{*}{ rakDa } \\
\hline & & & $\cdot / \mu \Lambda$ & $r / T r$ & شهربابك & \\
\hline \multirow[t]{2}{*}{ F } & \multirow[t]{2}{*}{.$/ 1$} & \multirow[t]{2}{*}{$r / \cdot \Lambda$} & $1 / \cdot r$ & $r / \Delta \Lambda$ & رفسنجان & \multirow[t]{2}{*}{$r \mathrm{rkDa}$} \\
\hline & & & $\cdot / r 1$ & $1 / r v$ & شهربابكك & \\
\hline \multirow[t]{2}{*}{ F } & \multirow[t]{2}{*}{.$/ \cdot 1$} & \multirow[t]{2}{*}{$-r / A}$. & $r / 4 r$ & YY/YY & رفسنجان & \multirow[t]{2}{*}{$\mathrm{rAkDa}$} \\
\hline & & & 91.9 & FANY & شهربابك & \\
\hline \multirow[t]{2}{*}{ F } & \multirow[t]{2}{*}{$\% r$} & \multirow[t]{2}{*}{$-V / N r$} & $\cdot / A F$ & TK/99 & رفنججان & \multirow[t]{2}{*}{ rokDa } \\
\hline & & & $1 / 41$ & $r 9 / 41$ & شهربابك & \\
\hline \multirow[t]{2}{*}{ f } & \multirow[t]{2}{*}{$\cdot / \mathrm{Na}^{2}$} & \multirow[t]{2}{*}{$\cdot / \Gamma \wedge$} & $F / \Delta 9$ & $r F / r V$ & رفسنجان & \multirow[t]{2}{*}{$r r k D a$} \\
\hline & & & $9 / 91$ & rY/lY & شهربابك & \\
\hline
\end{tabular}

Tollenaar ،(1998) Baskin و Baskin ،(1991) Fenner (2016) Jaganathan و مورد (2000) Gutterman ، (1999) بحث قرار گرفتهاند. گزارشهايى نيز وجود دارند كه تنوع بين

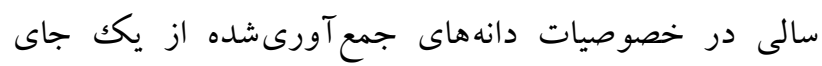

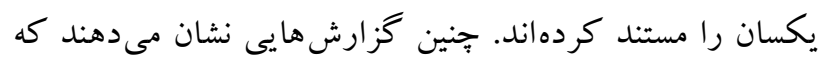
شرايط محيطى طى تكوين دانه مى تواند روى بسيارى از صفات رات ران

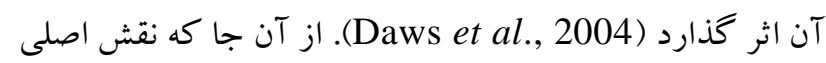

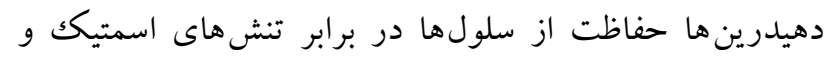
اكسايشى است، سلولهايى كه محتواى دهيدرين بالاترى دارند
سبس ميوه احاطه شده است، رطوبت هوا روى ميزان آب آن، تأثير بسزايى ندارد. بنابراين ميزان آب دو سرى دانه مشابه بود. اما دانه هاى شهربابك دوره خواب طولانى ترى نسبت به نهابـ

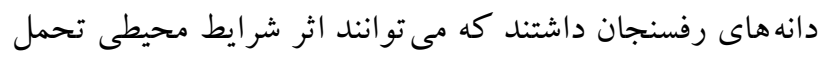
شده توسط گياه والد را نشان دهند. زيرا بهطور عمومى مستند

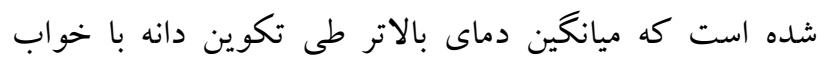

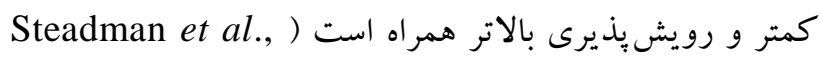
2004; Figueroa et al., 2010 همخوان است. اثر عوامل محيطى روى بلوغ دانه توسط 


\section{تيتيجه كيرى}

شرايط محيطى از جمله تأثير گذارترين عامل روى تعين صفات كياهان هستند. افرادى از يك كونه كه در شرايط محيطى متفاوتى تكوين يافتهاند، در خصوصيات ريختشناختى، زيستشيميايى و بسيارى از خصوصيات ديخر درجاتى از تنوع را به نمايش مى كذارند. نتايج ئزوهش حاضر نشان دادند كه محيط تكوين مى تواند روى صفات دانهها تأثير گذار باشد. دانهاى بِ بته تكوين يافته در دو محيط مختلف، از نظر رويش و برخى ويزگى هاى

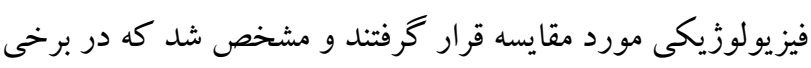
خصوصيات مانند طول دوره خفتخى و الخوى بيان برخى از يروتئينهاى دهيدرين متنوع بودند. تحقيق روى صفات بيشتر و تعيين ساز كارترين حالات اين صفات مى تواند راهى براى تشخيص بهترين محيطى باشد كه كياهان مفيد براى انسان مىتواند در آن يرورش يابند.

\section{سياسگز ارى}

نويسند گان بدينوسيله از بخش زيستشناسى دانشگاه شهيد باهنر كرمان براى تامين امكانات آزمايشگاهى قدردانى مى كنند.

\section{REFERENCES}

Baskin, C.C. and Baskin, J.M. 1998. Seeds - ecology, biogeography, and evolution of dormancy and germination. San Diego, CA, USA: Academic Press.

Banerjee, A and Roychoudhury, A. 2016. Group II late embryogenesis abundant (LEA) proteins: structural and functional aspects in plant abiotic stress. - Plant Growth. Regul. 79: 1-17.

Bradford, M.M. 1976. A rapid and sensitive method for the quantitation of microgram quantities of protein utilizing the principle of protein-dye binding. - Anal. Biochem. 72: 248-254.

Bremer, A., Wolff, M., Thalhammer, A. and Hincha, D.K. 2017. Folding of intrinsically disordered plant LEA proteins is driven by glycerol-induced crowding and the presence of membranes. - FEBS J. 284: 919-936.

Carjuzaa, P., Castellión, M., Distéfano, A.J., del Vas, M. and Maldonado, S. 2008. Detection and subcellular localization of dehydrin-like proteins in quinoa (Chenopodium quinoa Willd.) embryos. Protoplasma 233: 149-156.

Close, T. 1997. Dehydrins: A commonalty in the response of plants to dehydration and low temperature. Physiol. Plant. 100: 291-296.

Daws, MI., Lydall, E., Chmielarz, P., Leprince, O., Mathews, S., Thanos, C.A. and Pritchard, H.W. 2004. Developmental heat sum influences recalcitrant seed traits in Aesculus hippocastanum across Europe. New Phytol. 162: 157-166.
از حفاظت بالاترى برخوردارند (Panza et al., 2007). محورهاى رويانى منشا اصلى دانهرست هستند و نسبت به لِه ها، بيشتر حفاظتشده و محتواى دهيدرين بالاترى داشتند. بيشتر بودن محتواى دهيدرين محورهاى رويانى در گونه هاى ديخرى

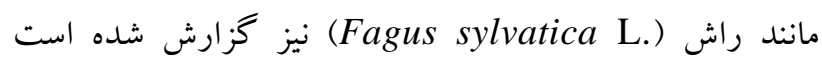
.(Kalemba \& Pukacka, 2008)

شرايط محيطى كذراندهشده طى تكوين دانه روى ميزان بيان دهيدرينها در لِهها تأثير مشخصى نداشتند، اما در محورهاى رويانى ميزان برخى از دهيدرينها از محيط تأثير بذيرفت. به طورى كه بيان دهيدرينهاى ها و Y Y كيلودالتونى در محورهاى رويانى دانهاى جمع آورىشده از شهربابكك بالاتر از دانه إى جمع آورىشده از رفسنجان بود. اما دهيدرين هب كيلودالتونى برخلاف دو دهيدرين WO و Y كيلودالتونى، در دانهاى رفسنجان بيان بالاترى داشت. تحقيقات روى دانه هاى جند كونه افرا (Acer) نيز نشان دادند كه بيان دهيدرينها در دانههايى كه از سالهاى مختلف از نظر شرايط آب و هوايى، برداشت شده بودند متفاوت بودند. بهطورى كه برخى از دهيدرينها در سالى

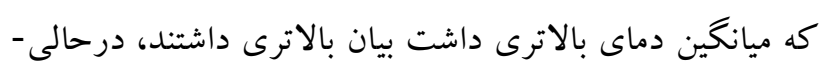
كalemba ( كه برخى ديخر در سال سردتر بيشتر مشاهده شدند

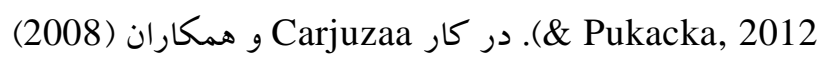
روى دانههاى كينوا (Chenopodium quinoa Willd.) جمع آورىشده از دو منطقه مختلف شامل منطقهاى كرم و

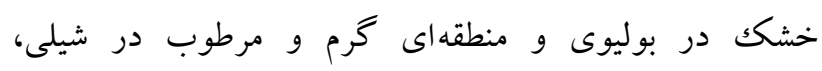
تحقيقات نشان دادند كه جهار دهيدرين در هر دو سرى دانه وجود داشتند و بيان دو عدد از آنها در دانههاى منطقه گرم و خشك دو برابر بيشتر بود. از طرفى جهار باند دهيدرين ديخر

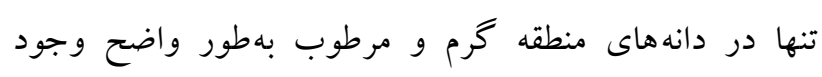
داشتند در حالى كه در سرى ديخر دانه مشاهده نشدند. اين محققين نتيجه كيرى كردند كه برخى از دهيدرينها بيان هميشكى و ثابت در دانه كينوا دارند و برخى از آنها ممكن برحئ

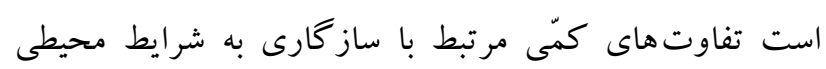
متفاوت را نشان دهند (Carjuzaa et al., 2008). تحقيقات بيشتر مورد نياز است تا نقش دقيق هر يكك از دهيدرينها در دانهاى يسته تعيين شود تا علت تأثير محيط بر بيان آنها مشخص شود. 
Fenner, M. 1991. The effects of the parent environment on seed germinability. - Seed 1: 75-84.

Fenner, M. 1992. Environmental influences on seed size and composition. - Hortic. Rev. 13: 183-213.

Figueroa, R., Herms, D.A., Cardina, J. and Doohan, D. 2010. Maternal environment effects on common groundsel (Senecio vulgaris) seed dormancy. - Weed Sci. 58: 160-166.

Gutterman, Y. 2000. Maternal effects on seeds during development. Pages 59-84 in: M. Fenner, (ed.). Seeds: The Ecology of Regeneration in Plant Communities. Wallingford, UK: CAB International.

Jaganathan, G.K. 2016. Influence of maternal environment in developing different levels of physical dormancy and its ecological significance. - Plant Ecology. 217: 71-79.

Kalemba, E.M. and Pukacka, S. 2008. Changes in late embryogenesis abundant proteins and a small heat shock protein during storage of beech (Fagus sylvatica L.) seeds. - Environ. Exper. Bot. 63: 274280.

Kalemba, E.M. and Pukacka, S. 2012. Association of protective proteins with dehydration and desiccation of orthodox and recalcitrant category seeds of three Acer genus species. - J. Plant Growth. Regul. 31: 351362.

Kermode, A.R. 1997. Approaches to elucidate the basis of desiccation-tolerance in seeds. - Seed Sci. Res. 7: 7595.

Laemmli, U.K. 1970. Cleavage of structural proteins during the assembly of the head of bacteriophage T4. - Nature 227: 680-685.

Mukherjee, K., Roychoudhury. A., Gupta. B., Gupta. S. and Sengupta, D.N. 2006. An ABRE binding factor, OSBZ8, is highly expressed in salt tolerant cultivars than in salt sensitive cultivars of indica rice. - BMC Plant Biol. 6: 1-14.

Panza, V., Distéfano, A.J., Carjuzaa, P., Láinez, V., Del Vas, M. and Maldonado, S. 2007. Detection of dehydrin-like proteins in embryos and endosperm of mature Euterpe edulis seeds. - Protoplasma 231: 1-5.

Saber Amoli, S., Naseri, A., Rahmani, G.H. and Kalirad, A. 2004. Medicinal Plants in Kerman Province. Iranian Medicinal and Aromatic Plants Research 20: 487-532.

Steadman, K.J., Ellery, A.J., Chapman, R., Moore, A. and Turner, N.C. 2004. Maturation temperature and rainfall influence seed dormancy characteristics of annual ryegrass (Lolium rigidum). - Aust. J. Agric. Res. 55: 1047-1057.

Takahashi, R., Joshee, N. and Kitagawa, Y. 1994. Induction of chilling resistance by water stress, and cDNA sequence analysis and expression of water stress-regulated genes in rice. - Plant Mol. Biol. 26(1): 339-352.

Tollenaar, M. 1999. Duration of the grain-filling period in maize is not affected by photoperiod and incident PPFD during vegetative phase. - Field Crops Res. 62: 15-21.

Vaseva, I.I, Anders, I. and Feller, U. 2014. Identification and expression of different dehydrin subclasses involved in the drought response of Trifolium repens. - J. Plant. Physiol. 171: 213-224.

Wang, Y., Xu, H., Zhu, H., Tao, Y., Zhang, G., Zhang, L., Zhang, C., Zhang, Z. and Ma. Z. 2014. Classification and expression diversification of wheat dehydrin genes. - Plant Sci. 214: 113-120.

Zamani Bahramabadi, E., Jonoubi, P. and Rezanejad, F. 2018. Ultrastructural changes of pistachio (Pistacia vera L.) mature seeds and pollen in relation to desiccation. - Trees 32: 29-39.

How to cite this article:

Zamani Bahramabadi1, E., Jonoubi, P. and Rezanejad, F. 2019. The effect of climate on water content, dormancy and dehydrins expression pattern in pistachio seeds. - Nova Biol. Reperta 6: 124-130.

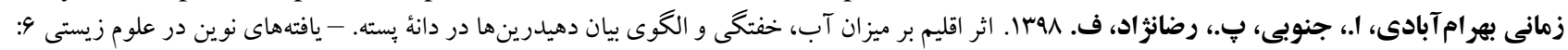

